\title{
OPTIMALISASI ASET WAKAF SEBAGAI SUMBER DANA PESANTREN MELALUI PELEMBAGAAN WAKAF (Studi Kasus Pelembagaan Wakaf Pesantren Baitul Hidayah)
}

\author{
Hendi Suhendi \\ Fakultas Dakwah Universitas Islam Bandung \\ hendisf.unisba@gmail.com
}

\begin{abstract}
ABSTRAK
Pesantren merupakan institusi penting yang telah memiliki peranan besar dalam proses pendidikan di Indonesia, karena terbukti telah berhasil mencetak lulusannya menjadi para pemimpin di negeri ini. Keberhasilan tersebut didukung faktor kemandirian keuangan pesantren melalui usaha-usaha produktif atau memproduktifkan asset-aset wakaf. Sebagai contoh, Pesantren Baitul Hidayah hanya memungut biaya makan para santri dan yang sanggup membayar sekitar $40 \%$ dari total santri. Untuk memenuhi kebutuhan biaya tersebut, Pesantren ini berusaha menciptakan sumber dana dengan cara memproduktifkan asset wakaf melalui kelembagaan wakaf. Dengan demikian tulisan ini berjudul "Optimalisasi Aset Wakaf sebagai Sumber Dana Pesantren melalui Pelembagaan Wakaf'. Secara rinci tulisan ini membahas tentang : (1) Pengertian wakaf. (2) Optimalisasi pengelolaan asset wakaf dalam aktivitas produktif. (3) Fundrasing wakaf. (4) Pesantren sebagai nadzir wakaf. (5) Proses pelembagaan wakaf. Adapun metode yang digunakan adalah studi kasus melalui pendekatan deskriptif kualitatif.
\end{abstract}

\section{Kata Kunci : Wakaf, Pesantren, Lembaga Wakaf}

\section{ABSTRACT}

Pesantren is an important institution that has big role in education process in Indonesia, because it proved succeeded in generating graduates become leaders in this country. This success is supported by the financiaxxl independence factor of pesantren through productive efforts or produces wakaf assets. For example, Pesantren Baitul Hidayah just picked meal costs for santri and even only $40 \%$ of the total santri can pay it. To fulfill these costs, this Pesantren trying to create source of fund by way of producing waqf assets through institutional waqf. Thus this paper entitled "Optimization of Waqf Assets as the Source of Pesantren Fund through Institutionalization of Waqf". In detail this paper discusses about: (1) Understanding waqf. $\quad$ (2) Optimization of waqf asset management in productive activities. (3) Fundrasing waqf. $\quad$ (4) Pesantren as nadzir waqf. (5) The process of institutionalization of waqf. The method used is case study through qualitative descriptive approach.

Keywords: Waqf, Pesantren, Waqf Institution 


\section{TAHKIM, Jurnal Peradaban dan Hukum Islam. Vol.1 No.1 (Maret, 2018), Hal. 1-20}

\section{A. PENDAHULUAN}

Pesantren merupakan institusi pendidikan yang sudah sejak lama berdiri, tumbuh dan berkembang di Indonesia. Pesantren memiliki peranan besar dalam mencerdaskan masyarakat jauh sebelum Indonesia merdeka. Sampai saat ini pesantren masih menjadi salah satu lembaga pilihan masyarakat dalam melaksanakan proses pendidikan bagi generasi muda, meskipun tantanganya sangat berat dan komplek.

Kondisi tersebut sebagai akibat semakin meningkatnya kebutuhan pembangunan dan kemajuan pengetahuan dan teknologi dalam rangka mengikuti modernisasi pendidikan ${ }^{1}$. Dampaknya semakin besarnya kebutuhan dana dalam proses pelaksanaan pendidikan dan pengembangan pesantren sebagai contoh kebutuhan fasilitas laboratorium computer, perpusatakaan yang representatif, asrama yang nyaman, sarana dan prasarana teknologi dan lain-lain. Dengan demikian, sesuatu yang wajar jika banyak pesantren modern yang memungut biaya pendidikan kepada santrinya dengan tarif mahal untuk memenuhi kebutuhan dana dalam proses pendidikan dan pengembangan pesantren.

Berbeda dengan pesantren modern lainnya, Pesantren Baitul Hidayah hanya memungut biaya makan kepada santrinya sebesar Rp 300.000 per bulan, itupun hanya 40\% yang membayar dari total santri yang ada. Pondok Pesantren Baitul Hidayah berada di Bukit Panyandaan, Mandala Mekar, Desa Cikadut, Kabupaten Bandung. Pondok pesantren ini didirikan di atas tanah wakaf seluas 1,5 Ha, dengan nomor akta wakaf 05/w.2/2009 dan berada di ketinggian 950 meter di atas permukaan laut ${ }^{2}$.

Pondok Pesantren Baitul Hidayah berada di bawah naungan Yayasan Baitul Hidayah Nurul Khalish. Saat ini, program pendidikan di Pondok Pesantren Baitul Hidayah sudah memasuki tahun keenam. Sudah lebih dari 175 santri yang datang dari berbagai wilayah di Indonesia (Medan, Padang, Bontang, Papua, Jawa Tengah, Jawa Timur) dengan dominasi wilayah Bandung dan sekitarnya. Secara umum program pesantren ini memadukan pola pesantren tradisional dan modern dengan corak terpadu antara sistem sekolah/madrasah dan sistem pesantren (asrama). Spesifiknya, program di Pondok

${ }^{1}$ Syahid Ismail, Strategi Mewujudkan Kemandirian Pesantren Berbasis Pemberdayaan Santri. Jurnal Prespektif Sosiologi, Vol 4 No 1, Januari 2016, hlm.56.

2 www.baitulhidayah.org 
Pesantren Baitul Hidayah ini adalah perpaduan antara program pendidikan, pengajaran dan Ihya Al-Qur'an.

Program pendidikan dengan pola pengasuhan 24 jam (pola pengasuhan berkiblat pada Pondok Modern Darussalam Gontor). Untuk program pengajaran, proses belajar mengajar dilakukan di kelas melalui sistem Kulliyatul-Mu'allimin Al-Islamiyah (KMI), kemudian untuk Program Ihya Al-Qur'an terdiri dari program Tahsin dan Tahfidz AlQur'an.

Santri juga diberikan program pendidikan Bahasa Arab, Bahasa Inggris, agama dan umum. Selain pelajaran akademik, kedepan santri yang ikut program ini juga dibekali life skill berupa ilmu pertanian, perkebunan, peternakan, perikanan, teknologi ramah lingkungan dan ilmu kewirausahaan untuk memenuhi kebutuhan sehari-hari dan orientasi pemberdayaan mereka kelak di kemudian hari ${ }^{3}$.

Berdasarkan hasil wawancara, dalam perjalanannya selama enam tahun banyak permasalahan yang dihadapi terutama aspek keuangan. Seluruh santri yang ada tidak dipungut biaya SPP (Sumbangan Pembinaan Pendidikan), hanya ada biaya makan sebesar Rp 300.000 (Tiga Ratus Ribu Rupiah) per orang, namun yang memenuhi biaya tersebut hanya $40 \%$ dari total santri yang ada. Dengan demikian, kebutuhan dana mulai dari pemenuhan sarana fisik pendidikan, operasional pendidikan dan kebutuhan hidup satri sehari-hari sangatlah besar. Untuk itu pesantren harus berupaya membangun kemandirian ekonomi. Pesantren pada hakikatnya dapat mandiri untuk menjadi pusat kelembagaan ekonomi bagi warganya didalam pesanten maupun diluar pesantren ${ }^{4}$. Untuk itu, Pesantren Baitul Hidayah merintis aktivitas ekonomi dengan membuka koperasi pesantren. Namun, untuk memenuhi kebutuhan yang cukup besar ikhtiar dari koperasi belum bisa mencukupi kebutuhan.

Usaha lain yang dilakukan adalah penggalangan donasi dari masyarakat, baik berupa zakat, infak, dan wakaf. Khusus bidang wakaf, Pesantren Baitul Hidayah memiliki peluang optimalisasi potensi wakaf yang bisa dikembangkan sehingga bisa menjadi sumber

${ }^{3}$ Pembekalan skill kepada santri merupakan hal yang penting, sebagai keterampilan untuk memenuhi tuntutan kehidupan kelak setelah selesai pendidikan dipesantren, selain itu keahlian tersebut dapat dijadikan modal untuk membentuk kegiatan usaha pesantren.

${ }^{4}$ Ahmad Faozan, Pondok Pesantren dan Pemberdayaan Ekonomi. Ibda, Vol 4 (1), 2006, hlm.88. 
TAHKIM, Jurnal Peradaban dan Hukum Islam. Vol.1 No.1 (Maret, 2018), Hal. 1-20

pendanaan dalam pengembangan dan pengelolaan pesantren, diantaranya : Pertama, keberadaan lahan wakaf, khususnya wakaf tanah dan bangunan. Wakaf tanah seluas 3,5 baru dimanfaatkan untuk bangunan pesantren seluas 1,5 Ha sehingga masih ada lahan 2 Ha yang dapat digunakan untuk aktivitas wakaf produktif terutama untuk kegiatan usaha pertanian dan peternakan. Selain itu, muwakif juga memberikan izin pemanfaat lahan milik muwakif diluar lahan wakaf seluas kurang lebih $6 \mathrm{Ha}$ jadi total ada $8 \mathrm{Ha}$ lahan yang dapat dimanfaatkan. Kedua, jaringan donatur dan calon donatur wakaf yang dimiliki, baik didalam negeri mapun diluar negeri. Sebagai contoh banyak bangunan pesantren yang didanai dari donasi wakaf individu masyarakat luar negeri, seperti Qatar dan Saudi. Ketiga, lokasi lahan wakaf yang memiliki pemandangan indah di puncak Bandung Utara, bisa menjadi kawasan wisata agro dan juga outbound. Keempat, Sumber Daya Manusia yang mengelola pesantren memiliki kompetensi pendidikan sarjana dan magister, sehingga memiliki potensi kemampuan yang dapat dioptimalkan tidak hanya sebatas guru pesantren. Keempat potensi tersebut jika dioptimalisasi maka akan berdampak terhadap pemenuhan kebutuhan pesantren. Karena jika wakaf didayagunakan dengan baik dan benar maka akan menciptakan kesejahtraan masyarakat ${ }^{5}$.

Untuk optimalisasi potensi tersebut maka diperlukan pengelolaan yang baik, terencana, terstruktur dan sistematis. Berdasarkan hasil observasi dan diskusi dengan para pengurus pesantren disimpulkan bahwa langkah penting yang harus dilakukan adalah pelembagaan wakaf sehingga potensi tersebut dapat di kelola oleh lembaga tersendiri dibawah naungan yayasan Baitul Hidayah Nurul Khalish. Dalam pengelolaan wakaf salah satu yang terpenting adalah nadzir wakaf, dimana di Indonesia nadzir wakaf adalah sekelompok orang atau lembaga yang diberikan tugas untuk mengelola wakaf ${ }^{6}$. Karena pengelolaan wakaf di Indonesia termasuk pesantren masih bersifat tradisional, kurang memperhatikan aspek-aspek kelembagaanya, standarisasi kemampuan para pengelolanya, manfaat dan pengembangan harta wakafnya ${ }^{7}$.

\footnotetext{
${ }^{5}$ Rahmat Dahlan, Analisis Kelembagaan Badan Wakaf Indonesia. Jurnal Bisnis dan Manajemen. Vol 6 No 1, April 2016, hlm. 116.

${ }^{6}$ Miftahul Huda, Fundraising Wakaf Pesantren Tebuireng Jombang dan Gontor Ponorogo. Jurnal Penelitian Keislaman, 6 (2), Juni 2010, hlm. 422.

${ }^{7}$ Ahmadan B. Lamuri, Pengelolaan Wakaf Alkhairat Palu Sulawesi Tengah. Jurnal Studia Islamika. Vol 11 No 2, Desember 2014, hlm. 315.
} 
Dengan demikian dalam tulisan ini, akan mencoba memberikan khasanah pemikiran dalam rangka optimalisasi asset wakaf sebagai sumber dana pesantren melalui pelembagaan wakaf. Secara rinci tulisan ini membahas tentang : (1) Pengertian wakaf. (2) Optimalisasi pengelolaan asset wakaf dalam aktivitas produktif. (3) Fundrasing wakaf. (4) Pesantren sebagai nadzir wakaf. (5) Proses pelembagaan wakaf di pesantren Baitul Hidayah. Adapun metode yang digunakan adalah study kasus melalui pendekatan deskriptif kualitatif.

\section{B. METODE PENELITIAN}

Penelitian ini merupakan penelitian studi kasus dengan menggunakan metode deskriptif, yaitu metode yang berusaha memutuskan pemecahan masalah yang ada sekarang berdasarkan data-data, jadi ia juga menyajikan data, menganalisis dan menginterprestasikan. Metode deskriptif bertujuan untuk melukiskan secara sistematis fakta dan cermat, sehingga hasil penelitian bersifat ilmiah yakni rasional, empiris dan sitematis ${ }^{8}$. Penggunaan metode tersebut dimaksudkan untuk menganalisa dan menyajikan fakta secara sistematis mengenai hal-hal yang berhubungan dengan judul penelitian sehingga dapat dengan mudah disimpulkan. Adapun pengumpulan data-data tersebut dengan menggunakan teknik observasi dan wawancara, karena kedua teknik tersebut yang relevan dengan kondisi objek penelitian. Kemudian jenis data yang dihimpun berupa data kualitatif diantaranya kata-kata, tindakan dan reallita-realita di lapangan ${ }^{9}$ selebihnya adalah data tambahan seperti dokumentasi dan lain-lain tentang pengelolaan asset wakaf dan program-program wakaf di Pesantren Biatul Hidayah.

\section{PEMBAHASAN}

\section{Pengertian Wakaf}

Secara etimologi waqaf berarti menahan, mencegah, selamanya, tetap, paham, menghubungkan, mencabut, meninggalkan dan lain sebagainya. wakaf adalah perbuatan seseorang untuk memisahkan sebagian harta benda/harta miliknya dimanfaatkan untuk kepentingan ibadah dan kesejahteraan umum ${ }^{10}$. Wakaf menurut Undang-Undang nomor 41

\footnotetext{
${ }^{8}$ Cholid Narbuko dkk, “Metode Penelitian, (Jakarta: PT. Bumi Aksara, 2002). Hlm. 44.

${ }^{9}$ Lexy J. Moleong, “Metode Penelitian Kualitatif”, (Bandung: Rosdakarya, 1990), hlm.112.

${ }^{10}$ Ma'luf dalam Abu Azam Al-Hadi, Upaya Pemberdayaan Tanah Wakaf Produktif Bagi Kesejahteraan Ummat, Jurnal ISLAMICA, Vol. 4 No. 1, September 2009, hlm.95.
} 
TAHKIM, Jurnal Peradaban dan Hukum Islam. Vol.1 No.1 (Maret, 2018), Hal. 1-20

tahun 2004 adalah: perbuatan hukum waqif untuk memisahkan dan/atau menyerahkan sebagian harta benda miliknya untuk dimanfaatkan selamanya atau untuk jangka waktu tertentu sesuai dengan kepentingan guna keperluan ibadah dan/atau kesejahteraan umum menurut shari'at ${ }^{11}$.

Wakaf menurut Peraturan Pemerintah nomor 28 tahun 1977 adalah: perbuatan hukum seseorang atau badan hukum yang memisahkan sebagian dari harga kekayaannya yang berupa tanah milik dan melembagakannya untuk selama-lamanya untuk kepentingan peribadatan atau keperluan umum lainnya sesuai dengan ajaran Islam. Sementara dalam Kompilasi Hukum Islam: adalah perbuatan hukum seseorang atau kelompok orang atau badan hukum yang memisahkan sebagian dari benda miliknya dan melembagakannya untuk selama-lamanya guna kepentingan ibadah atau keperluan umum lainnya sesuai dengan ajaran Islam.

Dari pengertian-pengertian diatas maka wakaf bisa dimaknai sebagai proses penyerah harta benda baik asset ataupun dana milik sesorang atau badan, kepada seseorang atau badan yang berperan sebagai nadzir dengan tujuan dikelola dan dimanfaatkan untuk kepentingan umat dalam jangka waktu yang lama.

Al Minawi dalam Suryani (2016), mengungkapkan definisi dan syarat-syarat wakaf yang di-rumuskan oleh para ahli fikih klasik lebih menitikberatkan kepada faktor keabadian benda yang diwakafkan ${ }^{12}$. Hal ini kemudian dipahami oleh sementara orang bahwa berwakaf harus dengan benda yang tahan lama (abadi) dan cendrung tidak bergerak (produktif). Selain itu definisi wakaf yang dibuat oleh para ahli fikih pada umumnya menyertakan syarat-syarat wakaf sesuai dengan mazhab yang dianutnya. Al-Mināwi misalnya mendefinisikan wakaf sebagai suatu upaya menahan harta benda yang dimiliki dan menyalurkan manfaat-nya dengan tetap menjaga pokok barang dan keabadiannya yang berasal dari para dermawan atau pihak umum, selain harta yang dihasilkan dari perbuatan maksiat semata-mata karena ingin mendekatkan diri kepada Allah. Sementara itu al-Kabisi dalam kitab Ānis al-Fuqahā' mendefinisikan wakaf dengan sebuah usaha menahan benda dalam kepemilikan wakif dan

\footnotetext{
${ }^{11}$ Republik Indonesia, Undang-undang no 41 tahun 2004

12 Al Minawi dalam Suryani dan Yunal Isra, Wakaf Produktif (Cash Waqf) Dalam Perspektif Hukum Islam Dan MaqāṢid Al-Sharī'Ah. Walisongo: Jurnal Penelitian Sosial Keagamaan, Vol. 24 No. 1, Mei 2016, hlm. 17. 
menyedekahkan manfaat-nya kepada orang-orang miskin dengan tetap menjaga keutuhan bendanya.

\section{Optimalisasi Pengelolaan Aset Wakaf dalam Aktivitas Produktif}

Fungsi wakaf sebagai pemberdaya ekonomi masyarakat masih belum optimal ${ }^{13}$. Hal ini mengingat mayoritas harta wakaf selama ini hanya dimanfaatkan untuk pembangungan keagamaan, yaitu masjid dan mushalla. Sedangkan pemanfaatan harta wakaf untuk sarana sosial dan kesejahteraan umat masih kurang mendapat perhatian. Fenomena di atas memang memiliki akar sejarah yang panjang terkait penyebaran agama Islam, di mana masjid menjadi elemen terpenting untuk pengembangan dakwah. Dari masjid, berkembang ajaran agama Islam yang saat ini dipeluk oleh mayoritas masyarakat. Namun demikian, ketika Islam sudah menyebar dalam masyarakat, bahkan bagi sebagian orang menjadi identitas utama dibandingkan dengan identitas bangsa sekalipun, lembaga wakaf tidak beranjak dari fungsi dan orientasi keagamaannya. Kondisi inilah yang kemudian memandulkan fungsi wakaf sebagai daya dorong bagi kesejahteraan masyarakat karena kebanyakan orang cenderung berwakaf untuk masjid dan kegiatan keagamaan. Senada dengan kasdi, Suryani (2016) Praktek wakaf di masa ini baru sebatas wakaf benda tidak bergerak dan diperuntukkan untuk kepentingan pembangunan fisik seperti masjid, mushalla, pesantren, kuburan, dan lain-lain ${ }^{14}$.

Namun, paradigma dan kondisi tersebut mulai berubah secara bertahap seiring dengan perubahan undang-undang no 41 tahun 2004 tentang wakaf, dimana harta wakaf harus dikelola secara produktif sehingga dapat berkontribusi dalam pengembangan ekonomi umat, termasuk didalamnya pengembangan pesantren. Untuk itu, asset wakaf yang dikelola para nadzir harus diproduktifkan.

Sebagai contoh pengelolaan asset wakaf Pesantren Modern Darussalam Gontor telah mengembangkan pengelolaan aset wakaf pesantren dengan menginvestasikan aset wakaf yang dikelolanya dalam bentuk unit- unit usaha berbasis manajemen modern. Saat diwakafnya pada tahun 1958 pesantren Gontor memiliki aset tanah sebanyak 18,59 hektar,

13 Abdurrahman Kasdi, Reinterpretasi Konsep Wakaf Menuju Pengembangan Wakaf Produktif : ZISWAF, Vol. 2, No. 1, Juni 2015, hlm. 158.

${ }^{14}$ Suryani, Wakaf Produktif (Cash Waqf) Dalam Perspektif Hukum Islam Dan MaqāṢid Al-Sharī'Ah. Walisongo: Jurnal Penelitian Sosial Keagamaan, Vol. 24 No. 1, Mei 2016, hlm.17-36. 
TAHKIM, Jurnal Peradaban dan Hukum Islam. Vol.1 No.1 (Maret, 2018), Hal. 1-20

maka pada tahun 2009 aset tanah pesantren ini berkembang menjadi 825,184 hektar, yang kurang lebih 651 hektar diantaranya merupakan tanah wakaf. Aset tanah tersebut diperoleh melalui wakaf, hibah, tukar menukar, dan pembelian. Di samping itu, pesantren ini telah menginvestasikan aset wakafnya dalam 27 unit usaha produktif ${ }^{15}$.

Contoh tersebut perlu ditiru untuk pesantren lain sepertihalnya pesantren Baitul Hidayah yang merupakan afiliasi dari Pesantren Darussalam Gontor. Asset wakaf Baitul Hidayah berupa wakaf tanah seluas 3,5 ha, sementara penggunaan untuk bangunan pesantren hanya 1,5 Ha sehingga masih ada lahan 2 Ha yang dapat dimanfaatkan untuk aktivitas wakaf produktif. Selain itu, muwakif juga memberikan izin pemanfaat lahan milik muwakif diluar lahan wakaf seluas kurang lebih 6,5 Ha jadi total ada 8 Ha lahan yang dapat dimanfaatkan. Selain luas, tanah wakaf tersebut berada dilokasi pegunungan dengan pemandangan yang indah yakni hamparan Kota Bandung. Potensi tersebut sangat sayang jika tidak diproduktifkan secara optimal.

Berdasarkan letak geografis dan kondisi alam di lahan wakaf Pesantren Baitul Hidayah, maka ada beberapa aktivitas produktif yang dapat dilakukan diantaranya : Pertama, Pemanfaatan lahan untuk peternakan. Sejak tahun 2012, aktivitas peternakan di pesantren baitul hidayah sudah dilakukan bekerjasam dengan Sinergi Foundation. Namun, pelaksanaan belum focus baru sebatas wadah pembelajaran para santri, sehingga belum bisa dijadikan sebagai sumber pendapatan untuk pengembangan pesantren. Agar lebih produktif maka pengelolaan peternakan harus dirubah menjadi aktivitas usaha dengan pendekatan majemen bisnis. Hal yang dapat dilakukan mulailah dengan aspek pemasaran sebagi contoh membuat usaha jasa layanan aqiqah dan kurban. Usaha tersebut akan menuntut proses pengelolaan ternak lebih professional dibanding sebelumnya karena ada kebutuhan pasar. Dengan demikian, efektivitas peternakan dapat dihitung berdasarkan jumlah kebutuhan hewan ternak untuk memenuhi layanan aqiqah dan kurban, kebutuhan lahan untuk pakan, SDM pengelola ternak, sarana dan prasarana ternak dan lain-lain. Hasil aktivitas peternakan tersebut seecara bertahap dapat dijadikan pendapatan pesantren.

${ }^{15}$ Achmad Siddiq, Wakaf Produktif Dan Problematikanya Di Dunia Pesantren. Millah Vol. XI, No 1, Agustus 2011, hlm.275. 
Kedua, pemanfaatan lahan untuk pertanian. Aktivitas pertanian sudah dilakukan jauh sebelum pesantren didirikan, namun saat itu yang dilakukan muwakif berupa penanaman pohon jati disekeliling lahan pesantren. Pohon jati bukan jenis pohon yang dalam waktu singkat dapat dipanen, jati memerlukan waktu tanam ideal selama 25 tahun, sehingga sampai saat ini pohon yang tumbuh belum bisa dijadikan sebagai sumber pendapatan pesantren. Kedepan perlu dilakukan aktivitas pertanian yang secara waktu lebih singkat juga produknya dibutuhkan pasar. Sebagai contoh adalah penanaman sayuran. Meskipun bukan hal yang mudah, namun sayuran secara waktu lebih singkat sehingga berpeluang menjadi sumber pendapatan pesantren. Peluang pasarpun terbuka, karena mulai dari pasar tradisonal seperti pasar cicaheum, juga pasar enduser yang merupakan masyarakat sekitar serta para jemaah pengajian tim asatid Pesantren Baitul Hidayah. Sebagai contoh dapat belajar dari aktivitas usaha agribisnis Pesantren al-Itifak Ciwidey, dimana usaha pertanian yang dilakukan dilahan wakaf dan lahan masyarakat sekitar dapat menjadi sumber pendapatan utama dalam memenuhi kebutuhan pendanaan pesantren.

Ketiga, Pemanfaatan lahan untuk outbond dan wisata pegunungan. Letak lahan wakaf yang tidak jauh dari pusat Kota Bandung, berpotensi dijadikan sebagai kawasan outbond dan wisata masyarakat Kota Bandung. Saat ini lokasi-lokasi wisata di wilayah sekitar Bandung menjadi tempat tujuan para turis domestic dan manca negara, sehingga setiap muslim liburan selalu dipadati pengunjung. Besarnya animo masyarakat untuk relak dan berwisata dialam menjadi peluang bagi Baitul Hidayah untuk memanfaatkan lahan wakafnya sebagai lokasi alternative wisata alam Bandung Utara.

Ketiga peluang pemanfaat lahan tersebut bukan hal yang tidak terpikirkan oleh para pengurus Pesantren Baitul Hidayah, namun sampai saat ini masalah klasik terkait dana pengelolaan menjadi dasar utama belum optimalnya lahan wakaf tersebut. Sebagai upaya penyediaan dana maka dapat dilakukan melalui kerjasama investasi usaha baik dengan individu ataupun lembaga. Hal lain adalah melakukan penghimpunan wakaf tunai yang dananya ditujukan untuk kegitan produktif pemanfaatan lahan tersebut. Akan tetapi, baik mencari investor ataupun menghimpun dana wakaf tunai bisa dilakukan secara optimal jika Pesantren Biatul Hidayah membentuk kelembagaan wakaf secara formal sebagai bagian dari Yayasan Baitul Hidayah Nurul Khalis. Manajemen lembaga wakaf menjadi bagian yang 
TAHKIM, Jurnal Peradaban dan Hukum Islam. Vol.1 No.1 (Maret, 2018), Hal. 1-20

paling krusial dalam memahami persoalan wakaf. Manajemen wakaf berkaitan dengan nadzir selaku pengelola wakaf, sistem pengelolaan wakaf, dan akuntabilitasnya. Hasil survey menunjukkan bahwa sebagian besar lembaga wakaf dikelola oleh perseorangan (66\%) dan selebihnya dikelola oleh nadzir organisasi dan badan hukum. Dibandingkan nadzir wakaf perseorangan, dalam berbagai aspek, ditemukan bahwa pengelolaan wakaf berbasis organisasi dan badan hukum secara umum lebih memungkinkan untuk diupayakan ke arah pengembangan wakaf ${ }^{16}$. Hal ini disebabkan adanya fakta di mana mayoritas pengelola wakaf yang notabene nadzir perseorangan bekerja paruh waktu (84\%) dan tidak mendapat imbalan.

\section{Fundraising Wakaf}

Fundraising wakaf merupakan aktivitas penghimpunan wakaf baik dari masyarakat secara individu, kelompok ataupun dari organisasi. Fundraising merupakan upaya jemput bola dalam rangka menggali dan mengoptimalkan potensi wakaf yang ada di masyarakat baik berupa uang, tanah, bangunan, peralatan, kendaraan dan asset lainnya. Fundrasing adalah aktivitas awal dalam alur manajemen tatakelola wakaf, yang kemudian dilanjutkan dengan pengelolaan harta wakaf serta pendayagunaan harta wakaf sesuai peruntukan yang diamanatkan oleh muwakif. Fundraising adalah upaya dalam rangka penyediaan modal dana untuk memanfaatkan asset wakaf yang telah tersedia agar dapat diproduktifkan melalui penghimpunan wakaf tunai.

Fundraising merupakan pengumpulan dana. Fundraising Campain berarti kampanye pengumpulan dana. Fundraising juga dapat diartikan sebagai kegiatan dalam rangka menghimpun dana dari masyarakat dan sumber daya lainnya dari masyarakat (baik individu, kelompok, organisasi, perusahaan ataupun pemerintah) yang akan digunakan untuk membiayai program dan kegiatan operasional organisasi/lembaga sehingga mencapai tujuannya. Adapun tujuan yang dimaksud adalah pengumpulan dana, penambahan muwakif,

peningkatan citra lembaga serta membangun loyalitas muwakif melalui beberapa unsur

\footnotetext{
${ }^{16}$ Abdurrahman Kasdi, Reinterpretasi..., hlm.158.
} 
diantaranya : kebutuhan wakif, segmentasi, positioning, produk, harga dan biaya transaksi, promosi, serta maintenance ${ }^{17}$.

Dengan demikian, Pesantren Baitul Hidayah penting melakukan aktivitas Fundrasing dana wakaf yang dapat dijadikan modal untuk pemanfaatan lahan wakaf yang tersedia, baik untuk kegiatan produktif bidang peternakan, pertanian atau wisata. Aktivitas tersebut tentu tidak bisa dilakukan dengan sertamerta tanpa strategi atau metode penghimpunan yang tepat sesuai sasaran wakif dan calon wakif yang ada. Secara umum metode penggalangan dana/daya nazhir pesantren dilakukan berdasarkan jenis sumber daya atau dana wakaf yang digalang oleh nazhir wakaf pesantren adalah menjadi tiga kategori utama, yakni menggalang dana/daya wakaf yang tersedia atau wakif baru, menciptakan dana baru (earned income) dan mengkapitalisasi atau mencipatakan dana dari sumber daya wakaf non finansial $^{18}$.

Secara sistematis upaya dalam proses fundraising yang dapat dilakukan oleh Baitul Hidayah sebagai berikut :

\section{(1) Perbaikan sistem kelembagaan}

Mengelola wakaf dan dana masyarakat lainnya tidak bisa asal kelola, perlu sistem atau manajemen kelembagaan yang baik. Adapun sistem kelembagaan tersebut, berkaitan dengan hal-hal berikut :

(a) Kedudukan Lembaga

Kedudukan lembaga yang independent dan profesional menjadi catatan penting. Kedudukan tersebut menjadi penting karena lembaga bisa menjangkau semua bagian masyarakat tanpa harus tersekat oleh politik, ras, suku bangsa atau hal lainnya, baik dalam menghimpun dana atau menyalurkan. Sehingga kehadiran lembaga betul-betul bisa menjadi wadah atau jembatan masyarakat dalam berwakaf.

(b) Visi misi lembaga

17 Jauhar Faradis, Manajemen Fundraising Wakaf Produktif: Perbandingan Wakaf Selangor (PWS) Malaysia dan Badan Wakaf Indonesia. Jurnal Asy-Syir'ah. Vol. 49, No. 2, Desember 2015. 500.

${ }^{18}$ Miftahul Huda, Fundraising Wakaf Dan Kemandirian Pesantren (Strategi Nazhir Wakaf Pesantren dalam Menggalang Sumber Daya Wakaf). ISLAMICA, Volume 7, Nomor 1, September 2012, 212. 


\section{TAHKIM, Jurnal Peradaban dan Hukum Islam. Vol.1 No.1 (Maret, 2018), Hal. 1-20}

Agar pengelolaan menjadi baik dan berjalan sesuai harapan maka, para pengurus lembaga wakaf perlu menentukan visi misi lembaga. Visi misi menjadi guide line perjalanan lembaga agar arahnya dari waktu kewaktu juga jelas, sehingga pengelolaan dapat dilakukan dengan baik. Selain itu, visi misi juga menjadi kekuatan untuk memotivasi para pengelola untuk terus bergerak mecapai mimpi besar sebagai wujud dari visi lembaga.

(c) Struktur Kelembagaan

Meskipun banyak keterbatasan, sebuah lembaga wakaf tetap perlu membuat struktur kelembagaan. Minimal bagian yang perlu ada dalam rangka menjalankan pengelolaan wakaf adalah penghimpunan, keuangan dan pendayagunaan.

Bagian penghimpunan bertugas untuk melakukan edukasi, sosialisasi, promosi, penerimaan dana, serta layanan terhadap muwakif. Namun jika secara sumberdaya bisa mencukupi bagian tersebut bisa dipecah kembali menjadi bagian marketing komunikasi, layanan donatur dan funding dana. Bagian keuangan bertugas mengelola dana, mulai dari pencatatan transaksi harian, jurnal, sampai laporan keuangan meliputi : arus kas, neraca, laporan peubahan dana dan lain-lain sesuai kebutuhan. Kemudian bagian pendayagunaan adalah bagian yang bergerak mendayagunakan dana atapun asset wakaf yang terhimpun untuk dimanfaatkan secara tepat dan memiliki multiflier effect, sesuai dengan amanah dari apara pewakaf (muwakif).

(d) Budaya lembaga

Budaya organisasi adalah sebuah sistem makna bersama yang dianut oleh para anggota yang membedakan suatu organisasi dari organisasi-organisasi lainnya. Sistem makna bersama ini adalah sekumpulan karakteristik kunci yang dijunjung tinggi oleh organisasi. Budaya organisasi berkaitan dengan bagaimana karyawan memahami karakteristik budaya suatu organisasi, dan tidak terkait dengan apakah karyawan menyukai karakteristik itu atau tidak. Budaya organisasi adalah suatu sikap deskriptif, bukan seperti kepuasan kerja yang lebih bersifat evaluatif.

\section{(2) Sosialisasi dan Promosi}

Edukasi, sosialisasi dan promosi adalah langkah untuk memahamkan masyarakat tentang wakaf, memberikan informasi kelembagaan dan program-program yang dijalankan, serta menarik mereka untuk mau menyalurkan wakaf melalui lembaga yang tepat. Untuk 
melakukan hal itu maka perlu melakukan optimalisasi media atau sarana diantaranya : media luar ruang, media cetak, media elektronik, atau pun media langsung seperti talk show, pengajian, diskusi, dan lain-lain.

\section{(3) Layanan kemudahan}

Sasaran penghimpunan yang kita maksud tentunya orang-orang yang memiliki harta, dan sudah dapat dipastikan orang-orang tersebut merupakan orang yang sibuk dengan beragam aktivitas. Dengan demikian layanan kemudahan merupakan hal yang cukup strategis untuk kita hadirkan, sehingga mereka mendapatkan tawaran solusi dalam menyalurkan dana untuk program yang kita tawarkan. Layanan kemudahan diantaranya : layanan transfer infak, jemput infak, auto debet, mobile konter (layanan stand infak di tempat-tempat pusat keramaian) dan lain-lain. Selain layanan kemudahan, hal lain yang harus dilakukan adalah menjalin silaturahmi yang kuat dengan mereka, serta memberikan laporan atas perolehan dana, serta penyaluran dana.

\section{Pesantren Sebagai Nadzir Wakaf}

Nazhir adalah pihak yang menerima harta benda wakaf dari Wakif untuk dikelola dan dikembangkan sesuai dengan peruntukannya. Nadzir wakaf bisa perseorang, organisasi atau badan hukum, dengan catatan memenuhi semua persyarat nadzir yang ada dalam undang-undang wakaf ${ }^{19}$. Nadzir mempunyai tugas melakukan pengadministrasian harta benda wakaf, mengelola dan mengembangkan harta benda wakaf sesuai dengan tujuan, fungsi, dan peruntukannya, mengawasi dan melindungi harta benda wakaf, dan melaporkan pelaksanaan tugas kepada Badan Wakaf Indonesia.

Pesantren yang merupakan lembaga pendidikan berbadan hukum yayasan dapat menjadi nadzir wakaf jika telah memenuhi persyaratan nadzir dan mengajukan sebagai nadzir wakaf kepada Badan Wakaf Indonesia. Namun pada umumnya pesantren yang selama ini menjadi pengelola wakaf baik dari keluarga pendiri atau dari masyarakat umum, kenadzirannya bersifat individu yang mana individu tersebut biasanya menjabat sebagai pengurus pesantren. Hal itu juga terjadi di Pesantren Baitul Hidayah, dimana wakaf lahan seluas 3.5 Ha dikelola oleh nadzir perseorangan yang berperan juga sebagai pengurus dan

\footnotetext{
${ }^{19}$ Republik Indonesia Undang-undang no 41 tahun 2004
} 
TAHKIM, Jurnal Peradaban dan Hukum Islam. Vol.1 No.1 (Maret, 2018), Hal. 1-20

pendiri pesantren. Kondisi tersebut menjadi salah satu faktor yang menghambat optimalisasi asset wakaf, karena focus utama dari para nadzir adalah sebagai guru atau pendidik di pesantren, sehingga pengelolaan wakaf belum dilakukan secara focus dan professional. Kedepan Pesantren Baitul Hidayah perlu mengupayakan secara serius dan sitematis membentuk kelembagaan wakaf yang akan berperan sebagai nadzir wakaf dalam mengelola asset-aset wakaf yang telah ada serta menghimpun harta wakaf yang baru juga menambah wakif-wakif yang baru pula.

Pentingnya pelembagaan wakaf karena pengelolaan wakaf berbasis organisasi dan badan hukum secara umum lebih memungkinkan untuk diupayakan ke arah pengembangan wakaf. Hal ini disebabkan adanya fakta di mana mayoritas pengelola wakaf yang notabene nadzir perseorangan bekerja paruh waktu (84\%) dan tidak mendapat imbalan, sehingga pengelolaan tidak focus dan kurang professional. Pengelolaan wakaf yang dilakukan oleh nadzir secara profesional memberi peluang bagi pengembangan wakaf agar lebih produktif, juga memberi peluang penerapan prinsip-prinsip manajemen modern. Dalam kerangka ini, nadzir harus berusaha untuk menampilkan performa terbaik wakaf yang mungkin dicapai ${ }^{20}$.

Parameter nadzir profesional adalah: (1) amanah (dapat dipercaya), (2) shiddiq (jujur), (3) fathanah (cerdas), dan (4) tablig (transparan). Sedangkan sumber daya nadzir yang amanah adalah: (1) terdidik dan tinggi moralitasnya, (2) memiliki keterampilan yang unggul dan berdaya saing, (3) memiliki kemampuan dalam melakukan pembagian kerja, (4) dapat melaksanakan kewajiban serta memperoleh hak yang adil, dan (5) memiliki standar operasional kerja yang jelas dan terarah ${ }^{21}$.

Dengan demikian peranan nadzir sangat strategis dan central dalam pengembangan wakaf. Semakin baik kualitas manajemen dan SDM yang ada dalam organisasi kenadziran, akan menentukan keberhasilan pengelolaan dan pemanfaatan harta wakaf dalam mensejahtrakan masyarakat termasuk dalam penyedia sumberdana pengembangan pesantren. Peningkatan akuntabilitas pengelolaan wakaf, sehingga terbentuk profesionalitas

\footnotetext{
${ }^{20}$ Kasdi.. ..,hlm.158.

${ }^{21}$ Ibid.
} 
pengelolaan wakaf yang dapat meningkatkan kepercayaan masyarakat ditentukan oleh kualitas nadzir wakaf ${ }^{22}$.

Uraian tersebut menguatkan perlunya tindakan perbaikan pengelola atau nadzir wakaf di Pesantren Biatul Hidayah melalui beberapa hal yakni : pelembagaan nadzir wakaf melalui pendirian lembaga wakaf sebagai unit organisasi dibawah yayasan Baitul hidayah, penentuan SDM khusus sebagai pengelola lembaga wakaf, pelatihan manajemen pengelolaan wakaf serta pemberian insentif untuk pengelola wakaf secara professional.

\section{Proses Pelembagaan Wakaf di Pesantren Baitul Hidayah}

Upaya optimalisasi penyediaan sumber dana untuk pengembangan pesantren melalui optimalisasi asset wakaf, fundraising wakaf, serta peningkatan peranan nadzir wakaf, semua berhubungan erat dengan kelembagaan wakaf, yakni pendirian lembaga wakaf dibawah naungan Yayasan Baitul Hidayah. Adapun proses pelembagaan wakaf Baitul Hidayah dilakukan melalui beberapa proses serta tahapan sebagai berikut :

1. Fokus Group Discussion (FGD). FGD merupakan salah satu teknik pengumpulan data kualitatif yang didesain untuk memperoleh informasi keinginan, kebutuhan, sudut pandang, kepercayaan dan pengalaman peserta tentang suatu topik dengan pengarahan seorang fasilitator atau moderator ${ }^{23}$. FGD tersebut akan dilakukan dalam beberapa tahap dan tema diantaranya :

a. FGD tahap 1, focus bahasan potensi wakaf Pesantren Baitul Hidayah. Hasil FGD merincikan beberapa potensi yang ada yakni : adanya lahan wakaf seluar $3.5 \mathrm{Ha}$ yang dapat dioptimalkan untuk sarana pendidikan dan kegiatan produktif, seperti pertanian, peternakan dan lain-lain. Pemandangan yang indah di lingkungan pesantren menjadi bagian dari potensi yang dapat dijadikan objek wisata religi, sehingga dapat mengundang masyarakat untuk dating kelingkungan pesantren, dengan demikian secara tidak langsung akan membawa dampak publikasi pesantren di masyarakat luas. Dimilikinya data donatur yang selama ini sudah berwakaf untuk

\footnotetext{
${ }^{22}$ Nurul Huda dkk, Akuntabilitas Sebagai Sebuah Solusi Pengelolaan Wakaf, Jurnal Akuntansi Multiparadigma, Volume 5 Nomor 3, Desember 2014, hlm. 345.

${ }^{23}$ Paramita dan Kristina (2013), Teknik Fokus Group Discussion dalam penelitian kualitatif. Buletin Penelitian Sistem Kesehatan, Vol 16, tahun 2013, hlm.122.
} 


\section{TAHKIM, Jurnal Peradaban dan Hukum Islam. Vol.1 No.1 (Maret, 2018), Hal. 1-20}

pelaksanaan kegiatan pesantren, data tersebut dapat dijadikan sebagai data awal untuk membangun data base donatur. Setiap ustad memiliki jaringan dan jemaah sehingga menjadi potensi prosfek donatur. Pondok pesantren merupakan bagian atau cabang dari Ponpes Darussalam Gotor, sehingga mudah dikenal masyarakat. Sudah dimilikinya sarana pendidikan.

b. FGD tahap 2, focus bahasan hasil analisis potensi wakaf Pesantren Baitul Hidayah

c. FGD tahap 3, focus bahasan model pengelolaan wakaf yang tepat untuk Pesantren Baitul Hidayah. Model pengelolaan yang tepat untuk Pesantren Baitul Hidayah adalah dengan membentuk unit khusus dibawah Yayasan Baitul Hidayah yang bergerak focus dalam pengelolaan wakaf, yang ditunjang oleh SDM khusus. Selama ini pengelolaan asset wakaf dilakukan oleh para ustad senior yang tugas utama mereka adalah melaksanakan pendidikan dan pengajaran, sehingga asset wakaf tidak terkelola dengan baik.

d. FGD tahap 4, focus bahasan penyusunan kelembagaan wakaf Pesantren Baitul Hidayah

e. FGD tahap 5, focus bahasan penyusunan buku panduan pengelolaan lembaga wakaf Pesantren Baitul Hidayah.

f. FGD tahap 6, focus bahasan rencana strategis pengembangan Pesantren Baitul Hidayah

2. Rapat pendirian dan soft launching lembaga wakaf, dilakukan bersama para pendiri dan stakeholder Pesantren Baitul Hidayah. Rapat tersebut bertujuan sebagai penetapan dan pengukuhan lembaga wakaf Pesantren Baitul Hidayah. Selain itu, momen tersebut dijadikan sebagai soft launching lembaga wakaf Pesantren Baitul Hidayah. Rapat tersebut memutuskan bahwa nama lembaga wakaf adalah Wakaf Foundation Baitul Hidayah. Selain nama lembaga, pengurus pun ditetapkan dengan cara menentukan nama-nama yang akan menjadi pengurus Wakaf Foundation.

3. Pengajuan izin lembaga wakaf ke Badan Wakaf Indonesia. Pengajuan izin dilakukan dengan cara mengajukan permohonan beserta memenuhi persyaratan yang telah ditentukan oleh Badan Wakaf Indonesia, yang merupakan lembaga resmi dengan tugas memberikan edukasi, arahan, pendampingan, dan pemberian izin nadzir wakaf. Adapun 
persyaratan dalam proses pengajuan izin diantaranya : Surat Permohonan pendaftaran nadzir wakaf, Struktur kepengurusan, daftar Riwayat Hidup pengurus badan, legalitas hukum, perubahan akta notaries, Surat keterangan domisili, Profil yayasan dan daftar harta atau asset yayasan, pernyataan memiliki biaya operasional, rencana kerja penghimpunan, pengelolaan dana dan pendayagunaan, rekomendari lembaga keuangan syariah, surat pernyataan bersedia memberikan laporan pelaksanaan dan surat pernyataan bersedia di audit.

4. Pelatihan pengelolaan lembaga wakaf untuk para pengurus lembaga wakaf Pesantren Baitul Hidayah. Untuk menjalankan pengelolaan awal lembaga wakaf yang telah dibentuk, maka perlu dilakukan pelatihan manajemen pengelolaan lembaga wakaf kepada para pengurus yang telah ditetapkan. Tahapan yang dilakukan dalam pelatihan manajemen pengelolaan wakaf sebagai berikut : pertama, Pre test. Hasil pretest menunjukan bahwa para pengurus yang telah ditunjuk untuk mengelola lembaga wakaf kedepan, masih belum memahami pola pengelolaan lembaga wakaf yang baik melalui pendekatan manajemen professional. Kedua, Pemaparan Materi. Pemaparan materi dilakukan melalui beberapa metode yakni, ceramah, diskusi, studi kasus dan tanya jawab. Materi disampaikan dalam 3 sesi, sesi pertama selama 120 menit berkaitan dengan manajemen penghimpunan dana wakaf, pelayanan terhadap donatur atau muwakif serta penataan data base para donator. Sesi kedua berkaitan dengan manajemen pengelolaan keuangan lembaga wakaf, dimana setiap peserta mendapatkan pemaparan berkaitan pengelolaan keuangan yang baik dan sesuai aturan undang-undang wakaf yang berlaku. Hal ini bertujuan agar lembaga bisa amanah, transparan dan terpercaya, sehingga semakin banyak masyarakat yang mau menitipkan dananya kepada lembaga wakaf tersebut. Sesi ketiga, materi focus pada manajemen pendayagunaan asset dan dana wakaf yang telah dihimpun, mulai dari proses perencanaan program sampai pada evaluasi program pendayagunaan yang dilakukan. Ketiga, Post test. Post test dilakukan dalam rangka mengevaluasi pemahaman para pengurus atau peserta pelatihan berkaitan dengan manajemen pengelolaan lembaga wakaf. Hasil post test menunjukan peningkatan pemahaman para pengurus berkaitan dengan pola manajemen pengelolaan wakaf setelah mendapatkan pemaparan. 
TAHKIM, Jurnal Peradaban dan Hukum Islam. Vol.1 No.1 (Maret, 2018), Hal. 1-20

\section{SIMPULAN}

Optimalisasi asset wakaf sebagai sumber dana pesantren melalui pelembagaan wakaf menjadi langkah konkrit yang harus dilakukan oleh pesantren khususnya Pesantren Baitul Hidayah. Upaya pelembagaan berhubungan erat dengan aktivitas fundraising dana wakaf yang sangat dibutuhkan oleh Pesantren Baitul Hidayah dalam rangka penyediaan modal untuk memproduktifkan lahan wakaf seluas 2 Ha ditambah 6 Ha lahan hak guna pakai, baik untuk kegiatan peternakan, pertanian ataupun wisata religi, sehingga hasil usaha tersebut dapat memenuhi kebutuhan dana pesantren. Hubungan tersebut ditunjukan adanya keterikatan pelembagaan dengan strategi fundraising yakni perbaikan kelembagaan melalui pembentukan lembaga, penentuan visi misi, kedudukan lembaga, struktur organisasi dan budaya lembaga. Selain itu, pelembagaan wakaf akan bedampak pada perbaikan peranan nadzir wakaf yang bertugas menghimpun, mengelola serta mendayagunakan harta wakaf sesuai dengan amanah muwakif. Karena riset membuktikan bahwa nadzir wakaf berbentuk organisasi atau badan hukum lebih berpeluang dalam mengoptimalkan pengelolaan wakaf dibanding nadzir perseorangan, yang berkativitas hanya paruh waktu dari tugas dan peranan masing-masing diluar pengelolaan wakaf, baik sebagai pekerja, pengusaha atau yang lainnya. 


\section{DAFTAR PUSTAKA}

Moleong, L.J. (1990). Metode Penelitian Kualitatif. Bandung: Rosdakarya.

Narbuko,C. et.al. (2002). Metode Penelitian. Jakarta: PT. Bumi Aksara.

\section{Jurnal/Artikel}

Al-Hadi, A.Z. (2009, September). Upaya Pemberdayaan Tanah Wakaf Produktif Bagi Kesejahteraan Ummat, Jurnal ISLAMICA, Vol. 4 (1). 95-107.

Dahlan, R. (2016, April). Analisis Kelembagaan Badan Wakaf Indonesia. Jurnal Bisnis dan Manajemen. Vol 6 (1). 116-117.

Faradis, J. et. al. (2015, Desember). Manajemen Fundraising Wakaf Produktif: Perbandingan Wakaf Selangor (PWS) Malaysia dan Badan Wakaf Indonesia. Jurnal AsySyir'ah. Vol. 49 (2). 500-518.

Faozan, A. (2006). Pondok Pesantren dan Pemberdayaan Ekonomi. Ibda. Vol. 4 (1), 88-102.

Huda, M. (2010, Juni). Fundraising Wakaf Pesantren Tebuireng Jombang dan Gontor Ponorogo. Jurnal Penelitian Keislaman, Vol.6 (2). 422-423.

. (2012, September). Fundraising Wakaf Dan Kemandirian Pesantren

(Strategi Nazhir Wakaf Pesantren dalam Menggalang Sumber Daya Wakaf). Jurnal ISLAMICA, Vol. 7 (1). 212-230.

Huda, N. et.al. (2014, Desember). Akuntabilitas Sebagai Sebuah Solusi Pengelolaan Wakaf. Jurnal Akuntansi Multiparadigma, Vol.5 (3). 345-510.

Ismail, S. (2016, Januari). Strategi Mewujudkan Kemandirian Pesantren Berbasis Pemberdayaan Santri. Jurnal Prespektif Sosiologi, Vol 4 No 1. 56-71.

Kasdi, A. (2014, Desember). Peran Nadzir Dalam Pengembangan Wakaf . Jurnal ZISWAF, Vol. 1 (2). 213-226.

. (2015, Juni). Reinterpretasi Konsep Wakaf Menuju Pengembangan Wakaf Produktif . Jurnal ZISWAF, Vol. 2 (1), 158-175.

Lamuri, A.B. (2014, Desember). Pengelolaan Wakaf Alkhairat Palu Sulawesi Tengah. Jurnal Studia Islamika. Vol. 11 (2). 315-346. 
TAHKIM, Jurnal Peradaban dan Hukum Islam. Vol.1 No.1 (Maret, 2018), Hal. 1-20

Siddiq, A. (2011, Agustus). Wakaf Produktif Dan Problematikanya Di Dunia Pesantren. Millah Vol. XI (1). 275-289.

Suryani, Isra, Y. (2016, Mei). Wakaf Produktif(Cash Waqf) Dalam Perspektif Hukum Islam Dan MaqāSSid Al-Sharī‘Ah. Walisongo: Jurnal Penelitian Sosial Keagamaan, Vol. 24 (1). 17-36.

Paramita, Kristina (2013), Teknik Fokus Group Discussion dalam penelitian kualitatif. Buletin Penelitian Sistem Kesehatan, Vol 16.122.

www.baitulhidayah.org 